\title{
EFIKASI DIRI DAN KREATIVITAS MENCIPTAKAN INOVASI GURU
}

\section{SELF-EFFICACY AND CREATIVITY TO CREATE TEACHER INNOVATION}

\author{
Nur Khayati \\ SMA Negeri 1 Cikarang Utara \\ Jalan K. Haji Dewantara No. 91, Cikarang Utara \\ e-mail: nurkayati.pch@gmail.com \\ Sri Sarjana \\ SMK Negeri 1 Cikarang Barat \\ Jl. Teuku Umar No. 1, Cikarang Barat \\ e-mail: srisarjana@gmail.com
}

Naskah diterima tanggal: 06/11/2014, Direvisi akhir tanggal: 25/08/2015, disetujui tanggal: 01/12/2015

\begin{abstract}
The objective of this research is to determine the influence of self efficacy and creativity on innovation. This research was conducted at the State Senior High school in North Cikarang Subdistrict, Bekasi district, using a survey method with path analysis technique. Research samples were selected using random sampling technique and consisted of as many as 123 teachers. The research revealed the following: 1) self efficacy has a positive and direct effect on teacher innovation, 2) creativity also has a positive and direct effect on teacher innovation, and 3) self efficacy has a positive and direct effect on teacher creativity. The conclusion of this research is that innovation can be improved by fostering self efficacy and creativity.
\end{abstract}

Keywords: Innovation, Self Efficacy, Creativity

\begin{abstract}
Abstrak: Tujuan penelitian ini yaitu untuk mengetahui pengaruh efikasi diri guru, dan kreativitas guru terhadap inovasi guru serta efikasi diri terhadap kreativitas guru dalam pembelajaran di sekolah. Penelitian ini dilaksanakan di SMA Negeri di Kecamatan Cikarang Utara Kabupaten Bekasi. Penelitian ini menggunakan metode survei dengan teknik analisis jalur. Sampel penelitian sebanyak 123 guru yang dipilih menggunakan teknik acak sederhana. Hasil penelitian menunjukkan bahwa: 1) efikasi diri memiliki pengaruh langsung positif terhadap inovasi guru; 2) kreativitas berpengaruh langsung positif terhadap inovasi guru; dan 3) efikasi diri berpengaruh langsung positif terhadap kreativitas guru. Simpulan dalam penelitian ini menunjukkan bahwa inovasi guru dalam pembelajaran di sekolah dapat ditingkatkan melalui efikasi diri dan kreativitas.
\end{abstract}

Kata kunci: inovasi, efikasi diri, kreativitas

\section{PENDAHULUAN}

Pendidikan, kreativitas, dan pemberdayaan ekonomi memiliki cakupan yang luas bagi para ahli di berbagai bidang keilmuan (Falola dan Abidogun, 2015). Pendidikan pada dasarnya sebagai upaya paling utama untuk mencerdaskan kehidupan bangsa guna menciptakan pembangunan kehidupan yang lebih beradab dan berbudaya. Hanya dengan pendidikan yang bermutu maka dapat tercipta keunggulan bangsa dalam menghadapi persaingan global yang semakin cepat dan kompetitif. Diperlukan pengelolaan pendidikan yang berorientasi pada bagaimana menciptakan perubahan yang lebih baik di masa yang akan datang. Sistem Pendidikan Nasional merupakan dasar penyelenggaraan dan reformasi pendidikan diatur dalam Undang-Undang Republik Indonesia 
Nomor 20 Tahun 2003. Undang-Undang tersebut memuat visi, misi, fungsi, dan tujuan Pendidikan Nasional yaitu untuk mewujudkan Pendidikan Nasional yang bermutu, relevan dengan kebutuhan masyarakat dan berdaya saing dalam kehidupan global.

Bidang teknik dan industri, pendidikan terus mengalami inovasi teknologi di era ekonomi baru untuk memenuhi tantangan dan tuntutan masyarakat (Chukwuedo dan Omofonmwan, 2015). Sekolah merupakan lembaga pendidikan yang strategis dalam mengupayakan peningkatan sumber daya manusia (SDM) yang bermutu, memiliki kemampuan untuk memanfaatkan, mengembangkan, menguasai ilmu pengetahuan dan teknologi. Sekolah menjadi instrumen penting untuk mampu menyiapkan SDM yang handal, kreatif, produktif, dan inovatif, yaitu manusia yang mampu menerima, mengolah, menyesuaikan, dan mengembangkan segala hal yang diperoleh melalui informasi.

Pembelajaran yang bermutu sangat diperlukan oleh setiap peserta didik. Memasuki era globalisasi sekarang, setiap peserta didik membutuhkan waktu untuk belajar. Keterbatasan waktu dan biaya dalam penyelenggaraan pendidikan dan pelatihan bagi tenaga pendidik dan tenaga kependidikan (PTK), dibutuhkan inovasi sistem pembelajaran yang berbasis teknologi informasi. Inovasi sistem pembelajaran akan terus berjalan secara dinamis dan berubah dari waktu ke waktu karena berbagai kebutuhan manusia untuk belajar semakin meningkat. Banyaknya faktor perubahan di era globalisasi turut serta berfungsi sebagai katalisator revolusi sistem pembelajaran dari sistem manual dan konvensional menjadi suatu sistem yang efektif dan efisien. Dengan demikian, dapat terwujud transformasi pengetahuan yang cepat dan mudah diakses oleh setiap PTK (Daryanto, 2013).

Ide, proses, dan hasil dari upaya inovasi yang dilakukan dalam dunia pendidikan tidak terlepas dari keberhasilan semua pihak, khususnya dalam dunia pendidikan dalam memaknai teknologi. Teknologi dipandang sebagai ide, proses, dan produk sehingga dari ketiga hal inilah pada akhirnya ada berbagai prosedur, pendekatan, strategi, model terbaru dalam dunia pendidikan dan pembelajaran. Pembelajaran yang mengadopsi hasil pikir dan rancang bangun suatu ide yang diwujudkan dalam produk tertentu dan memberikan kemudahan dalam pembelajaran menjadi salah satu pemahaman terhadap teknologi pembelajaran. Teknologi pembelajaran merupakan suatu ide dan rancang bangun tentang bagaimana suatu proses pembelajaran bisa berkualitas melalui pengukuran efektivitas dan efisiensi serta akselerasi pencapain perubahan perilaku peserta didik (Darmawan, 2012).

Masih banyak guru yang tidak inovatif, padahal guru masih dapat memanfaatkan internet untuk mengembangkan inovasi. Diantara 5,6 juta guru di Indonesia, baru sekitar $2 \%$ guru yang inovatif, artinya $98 \%$ guru tidak inovatif (Iskandar, 2013). Fenomena rendahnya inovasi guru juga terjadi di Kabupaten Bekasi. Menurut Saepulloh (2014) selaku Kepala Bidang Pembinaan Sekolah Menengah Dinas Pendidikan Kabupaten Bekasi. Rendahnya motivasi disebabkan antara lain belum mampunya guru dalam menyesuaikan diri dengan perubahan kurikulum, penguasaan teknologi yang masih rendah, proses pembelajaran tidak variatif dan masih menggunakan cara belajar yang lama, yaitu dengan menggunakan model ceramah, penggunaan buku cetak tanpa ada keinginan untuk membuat bahan ajar sendiri. Hal-hal tersebut mengindikasikan bahwa inovasi guru SMA Negeri di Kabupaten Bekasi masih rendah.

Inovasi menurut Ellitan dan Anatan (2009) adalah perubahan yang dilakukan dalam organisasi yang di dalamnya mencakup kreativitas dalam menciptakan produk baru, jasa, ide, maupun proses baru. Inovasi merupakan sistem aktivitas organisasi yang menstransformasi teknologi mulai dari ide sampai komersialisasi. Inovasi mengacu pada pembaruan suatu produk, proses dan jasa. Budaya inovasi merupakan nilai-nilai dan norma-norma anggota organisasi yang menjunjung tinggi 
kreativitas dalam inovasi untuk menciptakan keunggulan. Tanpa adanya budaya inovasi maka perilaku individu tidak akan mendorong terciptanya produk inovatif yang lebih unggul. Sa'ud (2012) berpendapat bahwa inovasi pendidikan merupakan suatu perubahan baru dan bersifat kualitatif yang berbeda dari sebelumnya, serta sengaja diusahakan untuk meningkatkan kemampuan guna mencapai tujuan tertentu dalam pendidikan. Pendidikan merupakan suatu sistem, maka inovasi pendidikan mencakup hal-hal yang berhubungan dengan komponen sistem pendidikan, baik sistem dalam arti sekolah, perguruan tinggi atau lembaga pendidikan yang lain maupun sistem dalam arti luas, misalnya sistem pendidikan nasional. Timbulnya inovasi dalam pendidikan disebabkan oleh adanya persoalan dan tantangan yang perlu dipecahkan dengan pemikiran baru yang mendalam dan progresif. Inovasi pendidikan merupakan upaya dasar untuk memperbaiki aspek-aspek pendidikan agar lebih efektif dan efisien.

Guru sebagai pendorong kreativitas menjadi hal yang sangat penting dalam pembelajaran. Guru dituntut untuk mendemonstrasikan dan menunjukkan proses kreativitas. Kreativitas merupakan sesuatu yang bersifat universal dan merupakan ciri aspek dunia kehidupan di sekitar kita. Kreativitas ditandai oleh adanya kegiatan menciptakan sesuatu yang sebelumnya tidak ada dan tidak dilakukan oleh seseorang atau adanya kecenderungan untuk menciptakan sesuatu. Sebagai guru yang kreatif, ia menyadari bahwa kreativitas merupakan hal yang universal karena semua kegiatan ditopang, dibimbing dan dibangkitkan oleh kesadaran itu. Guru adalah seorang kreator dan motivator yang berada dalam pusat proses pendidikan. Kreativitas guru menunjukkan bahwa apa yang dikerjakan oleh guru sekarang lebih baik dari yang telah dikerjakan sebelumnya dan apa yang dikerjakan guru di masa mendatang lebih baik dari sekarang (Mulyasa, 2010).

Efikasi diri adalah keyakinan akan kemampuan individu untuk memobilisasi motivasi, sumber kognisi, dan tindakan yang diperlukan untuk memenuhi tuntutan situasional yang diberikan (Schmitt dan Highhouse, 2012). Langkah-langkah kreativitas menurut Mullins (2005) terdiri atas tahap persiapan, merupakan tahap pertama proses kreatif yang meliputi pendidikan dan pelatihan formal. Inkubasi merupakan tahap konsentrasi dalam mendapatkan pengetahuan dan ide-ide yang diperoleh selama persiapan. Wawasan pengetahuan sebagai tahap ketiga dalam proses kreatif di mana semua pikiran dan ide-ide yang tersebar menghasilkan sebuah terobosan dan pembaharuan. Verifikasi sebagai tahap akhir proses kreatif untuk menentukan keabsahan atau pun kebenaran.

Tujuan penelitian ini yaitu untuk mengetahui: a) pengaruh efikasi diri terhadap inovasi guru; b) pengaruh kreativitas terhadap inovasi guru; dan c) pengaruh efikasi diri terhadap kreativitas guru SMA Negeri di Kecamatan Cikarang Utara Kabupaten Bekasi.

\section{KAJIAN LITERATUR}

\section{Inovasi}

Robbins dan Judge (2013) menjelaskan inovasi adalah suatu jenis perubahan khusus di mana suatu ide baru diterapkan untuk memulai atau meningkatkan suatu produk, proses, atau pelayanan. White dan Bruton (2011) mendefinisikan inovasi sebagai perubahan di mana produk, proses, material dan layanan baru atau yang sudah diperbaiki, dikembangkan dan ditransfer ke perusahaan atau pasar yang sesuai. Menurut Sattler (2011), inovasi adalah proses berulang yang diprakarsai oleh persepsi pasar yang baru atau peluang layanan yang baru untuk penemuan yang berbasis teknologi, bertujuan untuk pengembangan, produksi, dan tugas pemasaran untuk keberhasilan usaha dalam suatu penemuan yang benar-benar baru. Jeschke dan Hees (2013), menyatakan inovasi adalah realisasi dari ide-ide baru yang berkontribusi terhadap perubahan berkelanjutan. Inovasi menurut Griffin dan Moorhead (2014), inovasi adalah proses menciptakan dan 
melakukan hal-hal baru yang diperkenalkan ke dalam pasar sebagai produk, proses, atau layanan. Pitsis, Simpson dan Dehlin (2012) memaparkan konsep inovasi: Pertama, sebagai konsep temporal, inovasi adalah tentang perubahan atau adaptasi yang melibatkan "sebelum", "sekarang" dan "setelah" artinya selalu berbicara tentang masa lalu, sekarang dan masa depan. Kedua, inovasi adalah gambaran dan terjadi dalam konteks yang unik, cara untuk mengetahui dan memahami dunia.

Selanjutnya, Mullins (2005) menjelaskan bahwa inovasi sebagai proses pembaharuan dan kemajuan dalam semua kegiatan utama organisasi. Seperti halnya Mullin, inovasi menurut Web (2011) adalah proses menciptakan nilai yang luar biasa bagi pelanggan melalui proses mendengarkan yang aktif. Inovasi organisasi signifikan dalam mengembangkan dan meningkatkan produk terkait prosedur dan pasar untuk menambah nilai serta efektifitas secara administrasi dan inovasi sangat penting untuk mencapai dan mempertahankan keunggulan bersaing (Abdi dan Senin, 2015). Menurut Afuah (2009) inovasi baik produk atau proses bisnis adalah contoh yang baik dari nilai penciptaan permainan baru, melakukan sesuatu yang hasilnya berbeda dan harganya lebih murah. Kombinasi inovasi terjadi apabila adanya ketersediaan komponen atan bahan yang besar dan berbeda yang dapat dikombinasikan untuk menciptakan penemuan-penemuan baru (Peter dan James, 2015). Kegiatan inovatif sangat tergantung pada efisiensi operasional dari sistem inovasi (Reiljan dan Paltser, 2015). Menurut Bessant dan Tidd (2011), inovasi adalah penemuan yang konsisten yang menjadi ciri paling utama yang berhubungan dengan keberhasilan. Inovasi adalah alat khusus pengusaha yang sebagian besar memanfaatkan perubahan sebagai peluang untuk bisnis atau jasa yang berbeda. Hal ini mampu disajikan sebagai disiplin, pembelajaran, dan dipraktekkan.

Faktor-faktor dalam proses inovasi menurut Schermerhorn, Hunt, dan Osborn (2010) dimulai dari a) ide penciptaan melalui kreativitas spontan, kecerdikan dan pengolahan informasi, b) eksperimen sebagai tahap awal membangun nilai dan ide yang potensial, c) tekad sebagai kelayakan mengidentifikasi biaya dan manfaat, d) aplikasi akhir untuk memproduksi dan memasarkan produk atau jasa baru, atau untuk menerapkan pendekatan baru dalam operasional. Mekanisme yang digunakan untuk mendorong inovasi dan kreativitas dengan kriteria antara lain: a) kriteria alami yang tidak dapat ditentukan, b) pelanggan sebagai pendorong kualitas, c) perbaikan terus menerus sebagai siklus pembelajaran, d) menekankan untuk optimalisasi waktu kerja dalam operasionalisasi perusahaan, e) fokus pada kebutuhan pelanggan di masa depan.

Dari pengertian yang telah diuraikan di atas, dapat disintesiskan inovasi adalah perubahan diri sendiri maupun kelompok untuk meningkatkan kualitas melalui usaha yang sistematis dalam menjalankan tugas dengan indikator mengembangkan metode baru, mengembangkan hasil karya baru, mengembangkan strategi baru, menciptakan kesempatan baru, dan mengembangkan layanan baru.

\section{Efikasi Diri}

Menurut George dan Jones (2012) efikasi diri adalah keyakinan seseorang tentang kemampuannya untuk berhasil melakukan perilaku tertentu. Pendapat senada juga dijelaskan oleh Philips dan Gully (2012) bahwa efikasi diri adalah keyakinan seseorang pada kemampuannya untuk mengatur dan melakukan tindakan yang diperlukan untuk menyelesaikan tugas tertentu. Lebih lanjut, Philips menjelaskan bahwa efikasi diri adalah keyakinan umum bahwa seseorang akan berhasil pada tantangan ataupun tugas yang sulit. Menurut Daft (2011), efikasi diri adalah kapasitas melakukan keberhasilan sesuai prosedur, menganggap diri sebagai individu yang efektif. Seseorang dikatakan efektif apabila individu dapat memecahkan masalah dengan efektif, memaksimalkan peluang dan potensinya serta terus menerus belajar. Ketika individu 
menyadari kebutuhannya untuk berkembang, tingkat efektivitas yang dimiliki cenderung meningkat.

Griffin dan Moorhead (2014) berpendapat bahwa efikasi diri seseorang adalah sejauh mana seseorang percaya dapat mencapai tujuannya bahkan walaupun jika pernah gagal melakukannya di waktu yang lalu. Robbins dan Judge (2013) menjelaskan bahwa efikasi diri merujuk pada keyakinan individu bahwa ia mampu melakukan tugas. Semakin tinggi efikasi dirinya maka semakin yakin atau percaya mampu meraih keberhasilan. Dengan memiliki efikasi diri atau keyakinan yang tinggi, seseorang menjadi percaya atau yakin akan adanya kemungkinan keberhasilan dalam mengerjakan tugas-tugas tertentu. Peluang untuk mencapai keberhasilan akan tercapai pada tugas dengan tingkat kesulitan yang lebih tinggi dibandingkan dengan orang yang tidak memiliki efikasi atau dengan efikasi diri yang rendah. Sementara itu, Gibson, Ivancevich, Donnelly, dan Konopaske (2011), berpendapat bahwa efikasi diri didefinisikan sebagai keyakinan bahwa seseorang mampu tampil bekerja dalam situasi tertentu. Kemampuan seseorang dapat digunakan untuk mempengaruhi persepsi, motivasi dan kinerja. Dalam hal ini seseorang dapat berperan dalam situasi tertentu dengan menggunakan seluruh kemampuannya berdasarkan pada kepercayaan diri yang dimilikinya. Kondisi saat ini akan memperlihatkan seberapa baik seseorang melaksanakan tugas dalam mengambil tindakan yang diperlukan berkaitan dengan situasi yang akan terjadi.

Efikasi diri membangun konsep pengorganisasian yang layak untuk pengembangan model-model baru dan profesional. Efikasi diri menjadi ciri utama dari teori pembelajaran sosial dan memiliki peran sebagai faktor intervensi yang kuat antara belajar dan kinerja termasuk dalam pengembangan guru. Membangun efikasi diri dapat mengembangkankan sekolah dan pengembangan staf untuk merancang pelatihan guru yang efektif, meningkatkan kompetensi guru dan meningkatkan hasil belajar peserta didik (Vadahi dan Lesha, 2015). Guru dengan efikasi diri yang tinggi menjadi lebih bergairah dalam mengajar, siap menerima ide-ide baru dan mampu menggunakan metode pengajaran baru untuk membantu peserta didik dalam belajar dikarenakan guru dengan efikasi yang tinggi tersebut memiliki perilaku mengajar yang positif seperti kesabaran, komitmen dan semangat (Moalosi dan Forcheh, 2015). Integrasi model perilaku organisasi memberikan perspektif baru tentang pengaruh harapan dan efikasi diri pada etika (Swanepoel, Botha dan Rose-Innes, 2015). Pengembangan efikasi diri dilakukan melalui penyediaan pelatihan, pembinaan, dan pendampingan (Rachmawan, Lizar, dan Mangundjaya, 2015).

Kaitan antara efikasi diri dan inovasi dideskripsikan oleh Luthans (2011) bahwa efikasi diri memiliki dampak terhadap perilaku organisasi seperti karir dan pengembangan, pelatihan karyawan, peningkatan desain kerja, komunikasi, efikasi kolektif atau tim, inovasi, pengusaha, pemimpin dan stres. Pendidik harus mampu mengelola efikasi diri dan tingkat stres untuk meningkatkan kemampuan berpikir kritis bagi peserta didik (Kim, Lee, dan Park, 2015). Hsiao, Ya-Ling, Chang dan Chen (2011) menggambarkan wawasan yang penting pada efikasi diri guru dapat dimanfaatkan untuk mengembangkan perilaku inovasi guru dalam pekerjaannya. Guru dengan efikasi diri yang lebih tinggi memperlihatkan tingkat perilaku inovasi yang lebih tinggi. Hal itu merupakan cara yang terbaik untuk membangun efikasi diri guru. Dengan demikian dapat dipahami bahwa efikasi diri guru memiliki keterkaitan erat dengan kreativitas dan secara langsung maupun tidak langsung akan berdampak terhadap inovasi yang dilakukan oleh guru dalam sistem pembelajaran di sekolah.

Berdasarkan deskripsi di atas dapat disintesiskan bahwa efikasi diri adalah keyakinan seseorang dalam memaksimalkan usahanya dalam melaksanakan tugasnya dengan indikator: kesanggupan melaksanakan tugas, kesanggupan menyelesaikan tugas, kesanggupan menghadapi 
tantangan, kesanggupan menghadapi resiko, kesanggupan meningkatkan motivasi dan kesanggupan meningkatkan kinerja.

\section{Kreativitas}

Menurut Schermerhorn, Hunt, dan Osborn (2010) kreativitas menghasilkan generasi ide baru atau pendekatan yang unik untuk memecahkan masalah kerja mengeksploitasi peluang kerja. Definisi kreativitas menurut Martin (2008) sebagai suatu cara membuat atau menemukan produk baru dan berharga, yang dibuat secara resmi. Kreativitas menurut Stamm (2008) adalah tindakan dengan ide di posisi pertama, sebagai tindakan dasar individu. Dalam pengembangan ide dan pelaksanaanya keberadaan tim sangat dibutuhkan. Kreativitas merupakan bagian penting dari inovasi. Acton (2013) mendefinisikan kreativitas sebagai proses mengamati, mengeksploitasi, dan membangkitkan usaha ide baru selama kegiatan sosial dan material. Mumford (2012), mendefinisikan bahwa kreativitas adalah bentuk kinerja dengan kata lain sesuatu yang dihasilkan oleh individu maupun kelompok. Robbins dan Judge (2013) menyatakan pendapatnya bahwa sifat-sifat yang berhubungan dengan individu yang kreatif adalah kemerdekaan, percaya diri, berani mengambil resiko, memiliki tempat pengendalian internal, toleransi terhadap ambiguitas, membutuhkan struktur yang rendah dan memiliki ketekunan. Manajer, pemimpin, dan organisasi dapat menjadikan kreativitas menjadi suatu konteks yang unik dan kreativitas dapat berkembang secara dinamis dari waktu ke waktu sesuai kemampuan berfikirnya (Cummings, Bilton dan Ogilvie, 2015).

Okpara (2007) menjelaskan lebih detail kaitan kreativitas terhadap inovasi, yaitu bahwa kreativitas merupakan akar dari inovasi. Beule dan Nauwelaerts (2013) menjelaskan kreativitas organisasi bisa mendorong aliran ide-ide baru untuk proses pengembangan produk baru atau inovasi. Lee dan Tan (2012) lebih tegas menyimpulkan bahwa kreativitas berpengaruh terhadap implementasi inovasi. Pengembangan materi pembelajaran dapat lebih dinamis dan beragam melalui pengembangan tugas dan kegiatan yang menumbuhkan kreativitas guru dan peserta didik yang membutuhkan pemikiran kritis serta berpikir divergen (Hemati dan Raeesi, 2015). Kreativitas ilmiah dapat dibina dengan program intervensi yang spesifik dan faktorfaktor yang dapat mempengaruhi perkembangan kreativitas ilmiah tersebut (Chien dan Siew, 2015). Perancang dan pengembang kurikulum harus bekerja sama dengan guru sehingga menghasilkan bahan yang kongruen dengan kreativitas, kecerdasan emosional, dan strategi pembelajaran (Mall-Amiri dan Fekrazad, 2015). Dengan demikian dapat diketahui bahwa kreativitas sangat bergantung pada kemampuan dan kapabilitas sumber daya manusia dalam menghasilkan ide, gagasan dan metode untuk menghasilkan kebaruan maupun memperbaiki sesuatu hal yang sudah ada sebelumnya.

Berdasarkan deskripsi di atas dapat disintesakan kreativitas adalah perilaku untuk merancang, membentuk, membuat atau melakukan sesuatu dengan hal yang baru atau berbeda, menggunakan gagasan yang baru dan berbeda dari sebelumnya serta bermanfaat untuk meningkatkan inovasi. Kreativitas mengandung indikator memiliki rasa ingin tahu yang besar, memprakarsai suatu gagasan, mengajukan suatu gagasan yang berbeda dengan orang lain, kesediaan membuka diri dan tidak terpengaruh orang lain.

\section{METODE}

Penelitian ini dilaksanakan di SMA Negeri di Kecamatan Cikarang Utara Kabupaten Bekasi dengan obyek penelitan guru.

Penelitian dilaksanakan selama 3 bulan yaitu mulai bulan Maret sampai dengan bulan Mei 2014. Populasi dalam penelitian ini meliputi seluruh guru di SMA Negeri di Kecamatan Cikarang Utara Kabupaten Bekasi. Populasi terjangkau ialah guru pada tiga sekolah di SMA Negeri di Kecamatan Cikarang Utara Kabupaten Bekasi yang berjumlah 177 guru. Jumlah sampel dalam penelitian ini sebanyak 123 orang guru 
yang diperoleh dengan menggunakan rumus Slovin. Teknik pengambilan sampel menggunakan simple random sampling (Sugiyono, 2009). Hal ini bertujuan memberikan kesempatan yang sama pada setiap guru untuk diberikan kesempatan menjadi sampel pada penelitian ini.

Penelitian ini dilaksanakan dengan menggunakan metode survei dengan teknik analisis jalur (Bandur, 2014). Statistik deskriptif juga digunakan dalam penelitian ini, untuk mendiskripsikan data setiap variabel. Survei dilakukan dengan membagikan kuesioner yang berupa daftar pernyataan kepada sampel. Jenis kuesioner berstruktur dengan skala rating. Pernyataan telah disiapkan dengan beberapa alternatif jawaban yang sesuai dengan permasalahan dan tujuan penelitian. Sesuai dengan jumlah variabel, maka penelitian ini menggunakan tiga instrumen yaitu :1) instrumen yang mengukur inovasi; 2) instrumen yang mengukur efikasi diri; dan 3) instrumen yang mengukur kreativitas.

Variabel inovasi, efikasi diri, dan kreativitas guru diukur menggunakan skala peringkat berdasarkan pilihan jawaban responden terhadap setiap butir kuesioner yang diajukan. Skor setiap butir ditetapkan berdasarkan pilihan responden terhadap 5 alternatif respon atau jawaban yang diajukan. Jawaban "sangat sering" mendapat skor 5, "sering" mendapat skor 4, "kadangkadang" mendapat skor 3, "pernah" mendapat skor 2 dan "tidak pernah" mendapat skor 1. Sebelum instrumen digunakan, terlebih dahulu dilakukan uji validitas untuk mengukur tingkat keandalan dan kesahihan serta dilakukan perhitungan koefisien reliabilitas untuk menghitung keajegan dan taraf kepercayaan terhadap instrumen.

Teknik analisis data dalam penelitian ini menggunakan perhitungan statistika baik dalam pengolahan data penelitian maupun dalam analisis data penelitian yang terdiri atas a) statistika deskriptif yaitu untuk mendiskripsikan atau menggambarkan setiap variabel dalam bentuk rata-rata, modus, median, simpangan baku, tabel dan grafik; b) Statistik inferensial yaitu untuk menganalisis data dimaksudkan untuk menguji persyaratan analisis dan hipotesis yang telah diajukan. Sebelum uji hipotesis dilakukan uji persyaratan analisis yaitu uji normalitas data dan uji homogenitas. Uji normalitas galat taksiran dilakukan dengan menggunakan uji Liliefors. Dilanjutkan uji signifikansi dan linearitas regresi, untuk melihat ada tidaknya hubungan antara variabel eksogen ke-1 dan ke-2 dengan variabel endogen ke-3. Semua pengujian menggunakan taraf nyata 0,05 dan 0,01 ; c) Teknik statistik analisis jalur digunakan untuk melukiskan dan menguji model hubungan antar variabel yang berbentuk sebab akibat. Digunakan dua tipe variabel yaitu variabel eksogen dan variabel endogen. Variabel eksogen memberikan pengaruh baik langsung maupun tidak langsung terhadap variabel endogen. Variabel endogen adalah variabel yang dapat mempengaruhi variabel endogen lainnya. Sesuai dengan kerangka berpikir yang telah dikembangkan maka variabel endogen dalam penelitian ini adalah inovasi guru, sedangkan variabel eksogen meliputi efikasi diri dan kreativitas.

\section{HASIL DAN PEMBAHASAN}

Efikasi diri berpengaruh langsung positif terhadap inovasi guru. Hal ini dapat diartikan bahwa dengan memiliki efikasi diri yang tinggi maka guru akan dapat meningkatkan inovasi. Guru yang memiliki efikasi diri yang tinggi dalam pembelajaran di sekolah akan memiliki keyakinan dan motivasi yang lebih besar dalam mengembangkan dan memperbarui cara dan metode terkini untuk menciptakan ide dan gagasan baru dalam proses pembelajaran, sehingga inovasi pembelajaran di sekolah dapat dihasilkan sesuai harapan. Melalui peningkatan efikasi diri guru dalam pembelajaran maka inovasi dapat diciptakan dalam upaya untuk memperbaiki sistem dan hasil pembelajaran di sekolah. Guru SMA Negeri di Kecamatan Cikarang Utara dapat mengembangkan inovasi, salah satunya dengan meningkatkan efikasi diri dalam sistem pembelajaran di sekolah. 
Kreativitas berpengaruh langsung positif terhadap inovasi guru. Hal ini berarti bahwa guru yang memiliki kreativitas tinggi akan dapat meningkatkan inovasi. Guru dituntut memiliki kreativitas yang tinggi dalam proses pembelajaran di sekolah dengan harapan agar proses belajar mengajar dapat lebih menyenangkan dan tidak membosankan sehingga diharapkan guru mampu menciptakan pembelajaran yang lebih efektif dan efisien. Melalui kreativitas guru yang baik dan melalui penciptaan ide dan gagasan baru dalam pembelajaran maka inovasi dalam sistem belajar di sekolah dapat dihasilkan sesuai dengan tujuan yang diharapkan. Guru SMA Negeri di Kecamatan Cikarang Utara dapat menciptakan inovasi diantaranya dengan cara mengembangkan kreativitas pembelajarannya di sekolah.

Inovasi terjadi ketika seseorang memanfaatkan alat baru dan teknologi baru (Goatley dan Johnston, 2013). Inovasi bergantung pada kemampuan kritis dan kemampuan mutakhir dimana perusahaan tidak boleh terlalu bergantung pada penerimaan pengetahuan eksternal. Kemampuan kritis dan kemampuan mutakhir, tingkat penerimaan pengetahuan diantara mitra rantai suplai berpengaruh positif terhadap inovasi (Sun, 2013). Konsep kapabilitas dinamis mengacu pada proses dan menekankan pada gagasan untuk meningkatkan kinerja (Sarjana, 2015). Keyakinan guru mempengaruhi tujuan, bahan ajar, pola interaksi kelas, peran, praktik kelas dan lain-lain. Oleh karena itu, memperbarui kepercayaan mengajar adalah prasyarat inovasi pembelajaran. Guru harus memperbarui keyakinan mereka dan mengadopsi model pengajaran baru untuk memenuhi tuntutan inovasi (Lin, Chuang, dan Hsu, 2014). Calon pengusaha yang masuk ke program kewirausahaan yang memiliki kebutuhan yang tinggi untuk mencapainya diperlukan pengalaman hidup yang optimal, memperoleh pengetahuan dasar pribadi yang diperlukan untuk berlatih inovasi, dan menggunakan proses terbaik untuk menciptakan inovasi yang sukses (Degen, 2013). Proses kreatif mengarah pada stabilisasi inovasi. Struktur organisasi, karakteristik individu, metode pelatihan, dan praktek pedagogis dan isi pelatihan dapat menyediakan pola tertentu untuk memahami dan membimbing proses inovasi dalam organisasi (Pisanu dan Menapace, 2014). Menurut Celik, Iraz, Cakici, dan Celik (2014) terdapat hubungan positif pemberdayaan karyawan dengan organisasi kreativitas dan inovasi (Celik, Iraz, Cakici, dan Celik, 2014).

Efikasi diri berpengaruh langsung positif terhadap kreativitas guru. Hal ini berarti bahwa guru yang memiliki efikasi diri yang tinggi akan dapat meningkatkan kreativitas guru. Efikasi diri dapat dikembangkan melalui upaya guru dalam menguasai kompetensi dan keahlian sesuai dengan bidangnya maupun penguasaan kemampuan dalam pengembangan sistem pendidikan di sekolah sehingga guru mempunyai nilai keyakinan dan percaya diri yang lebih baik. Guru yang mampu meningkatkan efikasi diri dalam proses pembelajaran yang ditandai dengan keyakinan dan penguasaan program pembelajaran di sekolah dapat meningkatkan kreativitasnya dalam pengembangan pembelajaran. Guru SMA Negeri di Kecamatan Cikarang Utara dapat mengembangkan kreativitas melalui peningkatan efikasi diri guru dalam proses pembelajaran di sekolah.

Kreativitas individu merupakan faktor yang memperkuat efek pendidikan (Kania, 2013). Efikasi diri, kepercayaan dan penggunaan berdampak positif terhadap kepuasan pelanggan (Joshua dan Pudjani, 2014). Orang yang memiliki efikasi diri yang lebih tinggi memiliki kemandirian karir yang lebih tinggi, tekun belajar, dan dalam memotivasi diri (Zakeri dan Shahtalebi, 2014). Kreativitas merupakan proses mental dan sosial yang melibatkan penemuan ide-ide baru, konsep atau asosiasi baru dari pikiran kreatif dan sangat penting untuk inovasi ( Ng'ang'a, 2013). Terdapat hubungan yang signifikan antara kreativitas guru dengan pendekatan realistis dan idealis. Guru yang memiliki pendekatan realistis dan idealis lebih kreatif daripada mereka yang tidak memilikinya (Maktabi, Hanifi, dan 
Feizabadi, 2014). Guru mengukur peringkat tertinggi keberhasilan pengajaran berdasarkan penilaian tertinggi secara profesional dan pengetahuan. Guru dinilai kurang mempunyai kemampuan untuk meningkatkan keterlibatan siswa dan memanfaatkan penilaian dalam mendorong belajar siswa (Hand, 2014). Penting untuk menumbuhkan berpikir dan belajar dari pembangunan interaksi yang signifikan dengan orang lain, sosial budaya pada pendidikan dan kreativitas yang menyediakan kerangka kerja analitis (Elisondo, Donolo, dan Rinaudo, 2013). Mutu pembelajaran yang baik dan metode pembelajaran yang menyenangkan adalah hal yang semestinya diciptakan oleh guru dalam membimbing dan memberi penguatan kepada siswa di kelas (Sarjana, 2014).

Berdasarkan hasil penelitian diuraikan deskripsi data dari masing-masing variabel penelitian, uji persyaratan analisis, dan pengujian hipotesis. Hasil observasi di SMA Negeri di Cikarang Utara masih didapati guru yang kurang inovatif. Hal ini dibuktikan dengan masih banyaknya guru yang memakai metode ceramah dalam pembelajaran di kelas, tidak memanfaatkan fasilitas ilmu dan teknologi walaupun internet, komputer, laptop, bahkan infokus sudah terpasang di setiap kelas. Guru tidak melibatkan peserta didik dalam pembelajaran, sehingga peserta didik akan merasa bosan dan jenuh dengan model pembelajaran yang monoton.

\section{Deskripsi Data}

Pengukuran inovasi, efikasi diri dan kreativitas guru dapat dilihat pada Tabel 1, 2, dan 3. Instrumen Inovasi $\left(\mathrm{X}_{3}\right)$ yang diedarkan memuat 29 pernyataan. Berdasarkan hal tersebut maka skor yang didapat memiliki rentang antara 29 sampai 145. Data dari 123 responden diperoleh total skor 11183, menghasilkan skor minimal 63 dan skor maksimal 106. Berdasar perhitungan diperoleh rata-rata sebesar 90,918, median sebesar 92 dan modus 94. Standar deviasi sebesar 9,414 dan varians sebesar 88,62.

Distribusi frekuensi memiliki 8 kelompok kelas dengan 6 panjang kelas. Lebih jelas distribusi skor inovasi ditunjukkan dalam Tabel 1.

Berdasarkan Tabel 1 diketahui bahwa sejumlah 4 atau sekitar 3,252\% responden memiliki skor antara 63 sampai dengan 68. Kelas berikutnya memiliki skor antara 69 sampai 74 dimiliki sekitar $0,813 \%$ atau 1 responden. Kelompok skor data 75 sampai 80 dimiliki 12 responden atau sekitar 9,756\%. Kelompok skor data 81 sampai 86 memiliki 22 responden atau sekitar $17,886 \%$. Selanjutnya rentang skor 87 sampai 92 dimiliki oleh 27 responden atau sekitar $21,951 \%$. Modus termasuk dalam kelompok ini. $22,764 \%$ merupakan prosentase terbesar, diisi

Tabel 1 Distribusi Frekuensi Data Skor Inovasi

\begin{tabular}{|c|c|c|c|c|c|c|c|c|c|c|}
\hline \multirow{2}{*}{$\begin{array}{l}\text { Nomor } \\
\text { Kelas }\end{array}$} & \multirow{2}{*}{\multicolumn{3}{|c|}{ Kelas Interval }} & \multirow{2}{*}{\multicolumn{3}{|c|}{ Batas Kelas }} & \multicolumn{4}{|c|}{ Frekuensi } \\
\hline & & & & & & & \multirow{2}{*}{$\begin{array}{c}\text { Absolut } \\
4\end{array}$} & \multirow{2}{*}{$\begin{array}{r}\text { Relatif (\%) } \\
3.252\end{array}$} & \multirow{2}{*}{$\frac{\text { Kumulatif }}{4}$} & \multirow{2}{*}{$\begin{array}{c}\begin{array}{c}\text { Kumulatif } \\
(\%)\end{array} \\
3.252\end{array}$} \\
\hline 1 & 63 & - & 68 & 62.5 & - & 68.5 & & & & \\
\hline 2 & 69 & - & 74 & 68.5 & - & 74.5 & 1 & 0.8130 & 5 & 4.065 \\
\hline 3 & 75 & - & 80 & 74.5 & - & 80.5 & 12 & 9.7561 & 17 & 13.821 \\
\hline 4 & 81 & - & 86 & 80.5 & - & 86.5 & 22 & 17.8862 & 39 & 31.707 \\
\hline 5 & 87 & - & 92 & 86.5 & - & 92.5 & 27 & 21.9512 & 66 & 53.659 \\
\hline 6 & 93 & - & 98 & 92.5 & - & 98.5 & 28 & 22.7642 & 94 & 76.423 \\
\hline 7 & 99 & - & 104 & 98.5 & - & 104.5 & 22 & 17.8862 & 116 & 94.309 \\
\hline \multirow[t]{2}{*}{8} & 105 & - & 110 & 104.5 & - & 110.5 & 7 & 5.6911 & 123 & 100 \\
\hline & & & & & & & 123 & 100 & & \\
\hline
\end{tabular}

Sumber: data diolah 
oleh responden dengan skor antara 93 sampai dengan 98. Median terdapat di kelompok kelas ini. Dua puluh dua orang responden memiliki skor antara 99 sampai dengan 104. Sisanya, yaitu sebanyak 7 orang atau sekitar 5,691\%, memiliki rentang skor 105 sampai dengan 110 . Dengan demikian, secara teoritis skor rata-rata inovasi guru $22,764 \%$ dan skor diatas rata-rata inovasi guru $17.886 \%$ dan $5,691 \%$ atau total skor ratarata inovasi guru sebesar 46,33\%. Artinya terdapat 53,67\% skor inovasi guru di bawah rata-rata atau masih rendah. Hal ini didasarkan pada hasil pengukuran jawaban responden dalam skor inovasi guru. Dengan demikian, dapat diketahui bahwa inovasi guru SMA Negeri di Kecamatan Cikarang Utara masih perlu ditingkatkan.

Variabel Efikasi diri memiliki instrumen yang terdiri dari 29 pernyataan. Konsekuensinya, secara teori skor terendah adalah 29 dan tertinggi adalah 145. Data dari 123 responden diperoleh total skor 12234 , memiliki skor minimal 76 dan skor maksimal 118. Berdasarkan perhitungan diperoleh rata-rata sebesar 99,463, median sebesar 100 dan modus 102. Standard deviasi sebesar 9,229 dan varians sebesar 85,185 .

Distribusi frekuensi memiliki 8 kelompok kelas dengan panjang kelas 6 . Lebih jelas distribusi skor efikasi diri ditunjukkan oleh Tabel 2.
Berdasarkan Tabel 2 diketahui bahwa sejumlah 8 atau sekitar $6,504 \%$ responden memiliki skor antara 76 sampai dengan 81 . Kelas berikutnya memiliki skor antara 82 sampai 87 dimiliki sekitar 2,439\% responden tepatnya 3 orang guru. Kelompok skor data 88 sampai 93 dimiliki 15 responden atau sekitar 12,195\%. Tiga puluh satu orang atau 25,203\% berada pada rentang skor 94 sampai 99. 30,081\%, merupakan prosentase terbesar, diisi 37 oleh responden dengan dengan rentang skor antara 100 sampai dengan 105. Nilai mean dan median terdapat dalam kelas ini. Selanjutnya, rentang skor 106 sampai dengan 111 dimiliki oleh 16 responden atau sekitar 13,008\%. Kelas berikutnya dimiliki oleh 12 responden. Kelas ini memiliki skor antara 112 sampai dengan 117. Sisanya, yaitu sebanyak 1 orang atau sekitar $0,813 \%$, memiliki rentang skor antara 118 sampai dengan 123. Sehingga secara teoritis skor rata-rata efikasi diri guru 30,08\% dan skor diatas rata-rata efikasi diri guru $9,75 \%$ dan $0,8 \%$ atau total skor rata-rata efikasi diri sebesar $40,63 \%$. Artinya terdapat 59,37\% skor efikasi diri guru di bawah rata-rata atau masih rendah, hal ini didasarkan pada hasil pengukuran jawaban responden dalam skor efikasi diri guru. Dengan demikian, dapat diketahui bahwa efikasi diri guru SMA Negeri di Kecamatan Cikarang Utara masih perlu ditingkatkan.

Tabel 2 Distribusi Frekuensi Data Skor Efikasi Diri

\begin{tabular}{|c|c|c|c|c|c|c|c|c|c|c|}
\hline \multirow{3}{*}{$\begin{array}{c}\text { Nomor } \\
\text { Kelas }\end{array}$} & \multirow{2}{*}{\multicolumn{3}{|c|}{ Kelas Interval }} & \multirow{2}{*}{\multicolumn{3}{|c|}{ Batas Kelas }} & \multicolumn{4}{|c|}{ Frekuensi } \\
\hline & & & & & & & \multirow{2}{*}{$\frac{\text { Absolut }}{8}$} & \multirow{2}{*}{$\begin{array}{l}\begin{array}{c}\text { Relatif } \\
(\%)\end{array} \\
6.504\end{array}$} & \multirow{2}{*}{$\frac{\text { Kumulatif }}{8}$} & \multirow{2}{*}{$\begin{array}{c}\begin{array}{c}\text { Kumulatif } \\
(\%)\end{array} \\
6.5041\end{array}$} \\
\hline & 76 & - & 81 & 75.5 & - & 81.5 & & & & \\
\hline 2 & 82 & - & 87 & 81.5 & 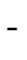 & 87.5 & 3 & 2.439 & 11 & 8.9431 \\
\hline 3 & 88 & - & 93 & 87.5 & - & 93.5 & 15 & 12.195 & 26 & 21.1382 \\
\hline 4 & 94 & - & 99 & 93.5 & - & 99.5 & 31 & 25.203 & 57 & 46.3415 \\
\hline 5 & 100 & - & 105 & 99.5 & - & 105.5 & 37 & 30.081 & 94 & 76.4228 \\
\hline 6 & 106 & - & 111 & 105.5 & 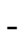 & 111.5 & 16 & 13.008 & 110 & 89.4309 \\
\hline 7 & 112 & - & 117 & 111.5 & - & 117.5 & 12 & 9.756 & 122 & 99.1870 \\
\hline \multirow[t]{2}{*}{8} & 118 & - & 123 & 117.5 & - & 123.5 & 1 & 0.813 & 123 & 100 \\
\hline & & & & & & & 123 & 100 & & \\
\hline
\end{tabular}

Sumber: data diolah 
Variabel Kreativitas memiliki instrumen yang terdiri dari 29 pernyataan. Konsekuensinya, secara teori skor terendah adalah 29 dan tertinggi adalah 145. Data dari 123 responden diperoleh total skor 9781, menghasilkan skor minimal 55 dan skor maksimal 94. Berdasarkan perhitungan diperoleh rata-rata sebesar 79,520, median sebesar 80 dan modus 83. Standard deviasi sebesar 9,09 dan varians sebesar 82,6451 .

Distribusi frekuensi memiliki 8 kelompok kelas dengan memiliki 5 panjang kelas. Lebih jelas distribusi skor kreativitas ditunjukkan oleh Tabel 3.

Berdasarkan Tabel 3 diketahui bahwa sejumlah 5 atau sekitar 4,065\% responden memiliki skor antara 55 sampai dengan 59. Sedangkan skor 60 sampai 64 dimiliki oleh 4 responden atau 3,252\%. Kelas berikutnya memiliki skor antara 65 sampai 69 dimiliki sekitar 4,065\% responden tepatnya 5 guru. Kelompok skor data 70 sampai 74 dimiliki 18 responden atau sekitar $14,634 \%$. Selanjutnya, rentang skor 75 sampai dengan 79 dimiliki oleh 26 responden atau sekitar 21,138\%. Sedangkan 28,455\% sebagai prosentase terbesar, diisi oleh responden dengan skor antara 80 sampai dengan 84 . Nilai median dan modus juga terdapat di rentang kelas ini. Kelas berikutnya juga dimiliki oleh 10 responden atau sekitar $8,130 \%$, kelas ini memiliki skor antara 85 sampai dengan 89 . Sisanya, yaitu sebanyak 20 orang atau sekitar $16,26 \%$, memiliki rentang skor antara 90 sampai dengan 94. Sehingga secara teoritis skor rata-rata kreativitas guru $28,45 \%$ dan skor diatas ratarata kreativitas $8,13 \%$ dan $16,26 \%$ atau total skor rata-rata dan di atas rata-rata kreativitas guru sebesar $52,84 \%$. Artinya terdapat $47,16 \%$ skor kreativitas guru di bawah rata-rata atau masih rendah, hal ini didasarkan pada hasil pengukuran jawaban responden dalam skor kreativitas guru. Dengan demikian, dapat diketahui bahwa kreativitas guru SMA Negeri di Kecamatan Cikarang Utara belum sesuai harapan.

\section{Pengujian Persyaratan Analisis Uji Normalitas Galat Taksiran}

Uji normalitas dilakukan terhadap hasil perhitungan galat taksiran dari setiap pasangan variabel bebas dan variabel terikat. Dalam hal ini dilakukan uji normalitas menggunakan teknik uji Liliefors. Kriteria yang digunakan dalam uji normalitas Liliefors adalah sebagai berikut: 1) Data berdistribusi normal jika nilai $\mathrm{L}_{\text {hitung }}<$ nilai $\mathrm{L}_{\text {tabel; }}$ 2) data dinyatakan tidak berdistribusi normal jika nilai $\mathrm{L}_{\text {hitung }}>$ nilai $\mathrm{L}_{\text {tabel. }}$

Berdasarkan Tabel 4 diperoleh hasil uji normalitas untuk setiap pasangan variabel sebagai berikut : (1) uji normalitas galat taksiran

Tabel 3 Distribusi Frekuensi Data Skor Kreativitas

\begin{tabular}{|c|c|c|c|c|c|c|c|c|}
\hline \multirow{3}{*}{$\begin{array}{c}\text { Nomor } \\
\text { Kelas }\end{array}$} & \multirow{2}{*}{\multicolumn{2}{|c|}{ Kelas Interval }} & \multirow{2}{*}{\multicolumn{2}{|c|}{ Batas Kelas }} & \multicolumn{4}{|c|}{ Frekuensi } \\
\hline & & & & & \multirow{2}{*}{$\frac{\text { Absolut }}{5}$} & \multirow{2}{*}{$\begin{array}{l}\begin{array}{c}\text { Relatif } \\
(\%)\end{array} \\
4.065\end{array}$} & \multirow{2}{*}{$\frac{\text { Kumulatif }}{5}$} & \multirow{2}{*}{$\begin{array}{c}\begin{array}{c}\text { Kumulatif } \\
(\%)\end{array} \\
4.0650\end{array}$} \\
\hline & 55 & 59 & 54.5 & 59.5 & & & & \\
\hline 2 & 60 & 64 & 59.5 & 64.5 & 4 & 3.252 & 9 & 7.3171 \\
\hline 3 & 65 & 69 & 64.5 & 69.5 & 5 & 4.065 & 14 & 11.3821 \\
\hline 4 & 70 & 74 & 69.5 & 74.5 & 18 & 14.634 & 32 & 26.0163 \\
\hline 5 & 75 & 79 & 74.5 & 79.5 & 26 & 21.138 & 58 & 47.1545 \\
\hline 6 & 80 & 84 & 79.5 & 84.5 & 35 & 28.455 & 93 & 75.6098 \\
\hline 7 & 85 & 89 & 84.5 & 89.5 & 10 & 8.130 & 103 & 83.7398 \\
\hline \multirow[t]{2}{*}{8} & 90 & 94 & 89.5 & 94.5 & 20 & 16.260 & 123 & 100 \\
\hline & & & & & 123 & 100 & & \\
\hline
\end{tabular}

Sumber: data diolah 
Tabel 4 Uji Normalitas Galat Taksiran

\begin{tabular}{ccrcc}
\hline $\begin{array}{c}\text { Galat Taksiran } \\
\text { Regresi }\end{array}$ & $\mathrm{N}$ & \multicolumn{1}{c}{ L Hitung } & $\mathrm{L}_{\text {Tabel }}$ & Hasil Pengujian \\
\hline X3 atas X1 & 123 & 0.062 & 0.0799 & Normal \\
X3 atas X2 & 123 & 0.0784 & 0.0799 & Normal \\
X2 atas X1 & 123 & 0.0733 & 0.0799 & Normal \\
\hline
\end{tabular}

Keterangan:

$\mathrm{X}_{1}=$ Efikasi Diri

$\mathrm{X}_{2}=$ Kreativitas

$\mathrm{X}_{3}=$ Inovasi

$\mathrm{N}=$ Banyak Sampel

inovasi $\left(X_{3}\right)$ atas efikasi diri $\left(X_{1}\right)$ diperoleh $L_{\text {hitung }}$ $=0,0620<L_{\text {tabel }}=0,0799$ pada $\alpha=0,05$ yang menunjukkan bahwa data berdistribusi normal sehingga persyaratan analisis dapat dipenuhi; (2) uji normalitas galat taksiran inovasi $\left(X_{3}\right)$ atas kreativitas $\left(X_{2}\right)$ diperoleh $L_{\text {hitung }}=0,0784<L_{\text {tabel }}=$ 0,0799 pada $\alpha=0,05$ yang menunjukkan data berdistribusi normal sehingga persyaratan analisis dapat dipenuhi; (3) uji normalitas galat taksiran kreativitas $\left(X_{2}\right)$ atas efikasi diri $\left(X_{1}\right)$ diperoleh $\mathrm{L}_{\text {hitung }}=0,0733<\mathrm{L}_{\text {tabel }}=0,0799$ pada $\alpha=0,05$ yang menunjukkan data berdistribusi normal sehingga persyaratan analisis dapat dipenuhi. Ketiga hasil uji yang dikemukakan di atas telah memperlihatkan bahwa data dalam penelitian ini telah memenuhi persyaratan analisis. Dengan demikian data tersebut dapat digunakan untuk menjelaskan pengaruh antarvariabel melalui teknik analisis jalur.

\section{Uji Signifikansi dan Linearitas}

Uji signifikansi dan linieritas regresi dilakukan terhadap masing-masing pasangan variabel yaitu efikasi diri $\left(X_{1}\right)$ dan inovasi $\left(X_{3}\right)$, kreativitas $\left(X_{2}\right)$ dan inovasi $\left(X_{3}\right)$, serta efikasi diri $\left(X_{1}\right)$ dan kreativitas $\left(X_{2}\right)$. Pengujian signifikansi dan linieritas regresi antara efikasi diri dengan inovasi diawali dengan menyusun persamaan regresi linier sederhana antara efikasi diri dan inovasi. Berdasarkan hasil perhitungan, hubungan linear antara inovasi $\left(\mathrm{X}_{3}\right)$ dan efikasi diri $\left(\mathrm{X}_{1}\right)$ diperoleh konstanta regresi $a=21,420$ dan koefisien regresi $b=0,699$. Dengan demikian hubungan model persamaan regresi yang tersusun pada perhitungan ini adalah $\hat{\mathrm{X}}_{3}=21,420+0,699 \mathrm{X}_{1}$. Hasil uji signifikansi pada baris regresi diperoleh $\mathrm{F}_{\text {hitung }}=107,011>\mathrm{F}_{\text {tabel }}=6,849$ pada $\alpha=0.01$ yang menunjukkan persamaan regresi yang sangat signifikan. Hasil uji Linearitas diperoleh $\mathrm{F}_{\text {hitung }}=$ $1,194<\mathrm{F}_{\text {tabel }}=1,564$ pada $\alpha=0.05$ yang menunjukkan persamaan regresi berbentuk linear. Hasil perhitungan uji signifikansi dan linieritas disusun pada tabel ANAVA yang tertera pada Tabel 5.

Pengujian signifikansi dan linieritas regresi antara inovasi dengan kreativitas diawali dengan menyusun persamaan regresi linier sederhana antara inovasi dan kreativitas. Berdasarkan hasil perhitungan, hubungan linear antara inovasi $\left(X_{3}\right)$ dan kreativitas $\left(X_{2}\right)$ diperoleh. Konstantan regresi $a=37,042$ dan koefisien regresi $b=$ 0,678 . Dengan demikian hubungan model persamaan regresi yang tersusun pada perhitungan ini adalah $\hat{\mathrm{X}}_{3}=37,042,913+$ $0,0678 X_{2}$. Hasil uji signifikansi pada baris regresi diperoleh $\mathrm{F}_{\text {hitung }}=107,011>\mathrm{F}_{\text {tabel }}=6,849 \mathrm{pada}$ $\alpha=0.01$ yang menunjukkan persamaan regresi yang sangat signifikan. Hasil uji Linearitas diperoleh $\mathrm{F}_{\text {hitung }}=1,217<\mathrm{F}_{\text {tabel }}=1,573$ pada $\alpha=0.05$ yang menunjukkan persamaan regresi berbentuk linear. Hasil perhitungan uji siginifikansi dan linieritas disusun pada tabel ANAVA seperti tertera pada Tabel 6.

Pengujian signifikansi dan linieritas regresi antara kreativitas dengan efikasi diri diawali dengan menyusun persamaan regresi linier 
Tabel 5 Tabel ANAVA Regresi Inovasi atas Efikasi Diri

Persamaan Regresi $\hat{X}_{3}=21,420+0,699 X_{1}$

\begin{tabular}{|c|c|c|c|c|c|c|}
\hline \multirow{3}{*}{ Sumber Varians } & \multirow{3}{*}{$\mathrm{dk}$} & \multirow{3}{*}{ JK } & \multirow{3}{*}{ RJK } & \multicolumn{3}{|c|}{ Uji F } \\
\hline & & & & \multirow{2}{*}{$\mathrm{F}_{\text {hitung }}$} & \multicolumn{2}{|c|}{$F_{\text {tabel }}$} \\
\hline & & & & & $\alpha=0,05$ & $\alpha=0,01$ \\
\hline Total & 123 & 1027555 & & & & \\
\hline Koefisien a & 1 & 1016743.813 & 1016743.8 & & & \\
\hline Regresi (bla) & 1 & 5073.938 & 5073.9377 & 107.011 & 3.919 & 6.849 \\
\hline Sisa & 121 & 5737.249 & 47.415 & & & \\
\hline Tuna cocok & 34 & 1824.870 & 53.673 & $1.194^{\mathrm{ns}}$ & 1.564 & 1.879 \\
\hline Galat & 87 & 3912.379 & 44.970 & & & \\
\hline
\end{tabular}

$* *$ ) : Regresi sangat signifikan ( $\left.F_{\text {hitung }}=107,011>F_{\text {tabel }}=6,849\right)$ pada $\alpha=0.01$

ns) : Regresi berbentuk Linear $\left(F_{\text {hitung }}=1,194<F_{\text {tabel }}=1,564\right)$ pada $\alpha=0.05$

dk : derajat kebebasan

RJK : Rata-rata Jumlah Kuadrat

JK : Jumlah Kuadrat

Tabel 6 Tabel ANAVA Regresi Inovasi $\left(\mathrm{X}_{3}\right)$ atas Kreativitas $\left(\mathrm{X}_{2}\right)$

Persamaan regresi $\hat{X}_{3}=37,042+0,0678 X_{2}$

\begin{tabular}{|c|c|c|c|c|c|c|}
\hline \multirow{3}{*}{ Sumber Varians } & \multirow{3}{*}{$\mathrm{dk}$} & \multirow{3}{*}{ JK } & \multirow{3}{*}{ RJK } & \multicolumn{3}{|c|}{ Uji F } \\
\hline & & & & \multirow{2}{*}{$F_{\text {hitung }}$} & \multicolumn{2}{|c|}{$F_{\text {tabel }}$} \\
\hline & & & & & $\alpha=0,05$ & $\alpha=0,01$ \\
\hline Total & 123 & 1027555 & & & & \\
\hline Koefisien a & 1 & 1017353.859 & 1017353.9 & & & \\
\hline Regresi (bla) & 1 & 4628.258 & 4628.2585 & 100.490 & 3.919 & 6.849 \\
\hline Sisa & 121 & 5572.882 & 46.057 & & & \\
\hline Tuna cocok & 32 & 1696.500 & 53.016 & $1.217^{\mathrm{ns}}$ & 1.573 & 1.895 \\
\hline Galat & 89 & 3876.382 & 43.555 & & & \\
\hline
\end{tabular}

Keterangan:

$* *$ ) : Regresi sangat signifikan ( $F_{\text {hitung }} 100,490>F_{\text {tabel }} 6,849$ ) pada $\alpha=0.01$

ns) : Regresi berbentuk Linear $\left(F_{\text {hitung }} 1,217<F_{\text {tabel }} 1,573\right)$ pada $\alpha=0.05$

$\mathrm{dk}$ : derajat kebebasan

RJK : Rata-rata Jumlah Kuadrat

JK : Jumlah Kuadrat

sederhana antara kreativitas dan efikasi diri. Berdasarkan hasil perhitungan, hubungan linear antara kreativitas $\left(X_{2}\right)$ dan efikasi diri $\left(X_{1}\right)$ diperoleh. Konstanta regresi $a=12,695$ dan koefisien regresi $b=0,672$. Dengan demikian, hubungan model persamaan regresi yang tersusun pada perhitungan ini adalah $\hat{\mathrm{X}}_{2}=$
$12,695+0,672 X_{1}$. Hasil uji signifikansi pada baris regresi diperoleh $\mathrm{F}_{\text {hitung }}=105,281>\mathrm{F}_{\text {tabel }}=3,919$ pada $\alpha=0.05$ dan 6,849 pada $\alpha=0.01$ yang menunjukkan persamaan regresi yang sangat signifikan. Hasil uji Linearitas diperoleh $\mathrm{F}_{\text {hitung }}=$ $0,893<\mathrm{F}_{\text {tabel }}=1,556$ pada $\alpha=0.05$ yang menunjukkan persamaan regresi berbentuk 
linear. Hasil perhitungan uji siginifikansi dan linieritas disusun pada tabel ANAVA seperti tertera pada Tabel 7.

\section{Pengujian Hipotesis \\ Teknik Analisis Jalur}

Hipotesis dalam penelitian ini diuji untuk menjelaskan pengaruh antar variable sebagai berikut: 1) pengaruh langsung efikasi diri terhadap inovasi; 2) pengaruh langsung kreativitas terhadap inovasi; 3) pengaruh langsung efikasi diri terhadap kreativitas. Langkah uji hipotesis di antaranya menyusun matrik korelasi antarvariable penelitian.

Berdasarkan hasil perhitungan koefisien jalur maka pengaruh efikasi diri terhadap inovasi dapat diketahui dari nilai korelasi koefisien jalur yang menunjukkan pengaruh efikasi diri terhadap inovasi sebesar 0,4465. Hasil uji signifikansi diperoleh $t_{\text {hitung }}=5,2439>t_{\text {tabel }}=2,617$ pada $\alpha=$ 0,01 yang menunjukkan koefisien jalur sangat signifikan. Hal tersebut dapat disimpulkan bahwa terdapat pengaruh langsung dan positif antara efikasi diri terhadap inovasi. Artinya, peningkatan efikasi diri akan mengakibatkan peningkatan inovasi. Hasil penelitian ini menunjukkan bahwa efikasi diri berpengaruh positif langsung terhadap inovasi ditemukan melalui analisis data dengan koefisien korelasi $r_{13}=0,685$ dan koefisien jalur $p_{31}=0,4465$. Penelitian ini sejalan dengan penelitian yang dilakukan oleh Hsiao, Ya-Ling, Chang dan Chen (2011) bahwa wawasan yang penting pada efikasi diri guru dapat dimanfaatkan untuk mengembangkan perilaku inovasi guru dalam pekerjaannya. Berdasarkan uraian di atas maka terdapat pengaruh langsung positif antara efikasi diri guru terhadap inovasi guru. Dengan demikian semakin tinggi efikasi diri guru maka semakin meningkat tingkat inovasinya. Guru yang memiliki tingkat efikasi diri yang tinggi dalam pembelajaran di sekolah akan memiliki keyakinan dan motivasi yang lebih besar dalam mengembangkan dan memperbarui cara dan metode terkini untuk menciptakan ide dan gagasan baru dalam proses pembelajaran, sehingga inovasi pembelajaran dapat dihasilkan sesuai harapan.

Berdasarkan hasil perhitungan koefisien jalur maka pengaruh kreativitas terhadap inovasi

Tabel 7 ANAVA Regresi Kreativitas $\left(X_{2}\right)$ atas Efikasi Diri $\left(X_{1}\right)$

$$
\text { Persamaan Regresi } \hat{X}_{2}=12,695+0,672 X_{1}
$$

Keterangan:

$* *$ ) : Regresi sangat signifikan ( $F_{\text {hitung }} 105,281>F_{\text {tabel }} 6,849$ ) pada $\alpha=0.01$

ns) : Regresi berbentuk Linear $\left(F_{\text {hitung }} 0,893<F_{\text {tabel }} 1,556\right)$ pada $\alpha=0.05$

dk : derajat kebebasan

RJK : Rata-rata Jumlah Kuadrat

JK : Jumlah Kuadrat 
dapat diketahui dari nilai korelasi koefisien jalur yang menunjukkan pengaruh kreativitas terhadap inovasi sebesar 0,3497. Hasil uji signifikansi diperoleh $t_{\text {hitung }}=4,1069>t_{\text {tabel }}=$ 2,617 pada $\alpha=0,01$ yang menunjukkan koefisien jalur sangat signifikan. Hal tersebut dapat disimpulkan bahwa terdapat pengaruh langsung dan positif antara kreativitas dengan inovasi, artinya peningkatan kreativitas akan mengakibatkan peningkatan inovasi. Hasil penelitian ini menunjukkan bahwa kreativitas berpengaruh langsung secara positif terhadap inovasi ditemukan melalui analisis data dengan koefisien korelasi $r_{23}=0,654$ dan koefisien jalur $p_{32}=$ 0,3497 . Hasil penelitian ini sejalan dengan penelitian yang dilakukan oleh Beule dan Nauwelaerts (2013) bahwasanya kreativitas organisasi merupakan pendorong yang penting untuk inovasi. Berdasarkan uraian di atas maka terdapat pengaruh langsung positif antara kreativitas guru terhadap inovasi guru. Dengan demikian, semakin tinggi kreativitas guru maka semakin meningkat inovasinya. Guru dituntut memiliki kreativitas yang tinggi dalam proses pembelajaran di sekolah dengan harapan agar proses belajar mengajar dapat lebih menyenangkan dan tidak membosankan sehingga diharapkan guru mampu menciptakan pembelajaran yang efektif dan efisien. Melalui kreativitas guru yang baik dan melalui penciptaan ide dan gagasan baru dalam pembelajaran maka inovasi dalam sistem belajar di sekolah dapat dihasilkan sesuai dengan tujuan yang diharapkan.

Berdasarkan hasil perhitungan koefisien jalur maka pengaruh efikasi diri terhadap kreativitas dapat diketahui dari nilai korelasi koefisien jalur yang menunjukkan pengaruh efikasi diri terhadap kreativitas sebesar 0,682. Hasil uji signifikansi diperoleh $t_{\text {hitung }}=10,2606>t_{\text {tabel }}=2,617$ pada $\alpha$ $=0,01$ yang menunjukkan koefisien jalur sangat signifikan. Dapat disimpulkan bahwa terdapat pengaruh langsung dan positif antara efikasi diri terhadap kreativitas. Artinya, peningkatan efikasi diri guru akan mengakibatkan peningkatan kreativitas guru. Hasil penelitian ini menunjukkan bahwa efikasi diri berpengaruh positif langsung terhadap kreativitas. Besarnya pengaruh tersebut ditemukan melalui analisis data dengan koefisien korelasi $r_{12}=0,682$ dan koefisien jalur $\mathrm{p}_{21}=0,682$. Hasil penelitian ini sejalan juga dengan penjelasan Bandura dalam Kreitner dan Kinichi (2007) mengemukakan tentang pengaruh efikasi diri terhadap kreativitas bahwa peningkatan efikasi diri seorang guru akan berpengaruh pada peningkatan kreativitas guru, sehingga berdampak pada maksimalnya pembelajaran kepada para siswa. Individu yang percaya diri dalam melaksanakan pekerjaan, akan berusaha lebih keras dan lebih kreatif untuk dapat meraih kesuksesan. Sebaliknya, jika terjadi krisis kepercayaan diri terjadi pada seorang individu maka akan mengarah pada kegagalan. Berdasarkan uraian di atas, terdapat pengaruh langsung positif efikasi diri terhadap kreativitas guru. Dengan demikian, dapat dinyatakan bahwa semakin baik dan semakin tinggi efikasi diri yang dimiliki guru maka guru akan semakin meningkat kreativitasnya. Guru yang mampu meningkatkan efikasi diri dalam proses pembelajaran ditandai dengan keyakinan dan penguasaan sistem pembelajaran di sekolah dapat meningkatkan kreativitasnya dalam pengembangan pembelajaran.

Hasil penghitungan analisis jalur berdasarkan model empiris dalam penelitian ini dirangkum dalam Gambar 1. 


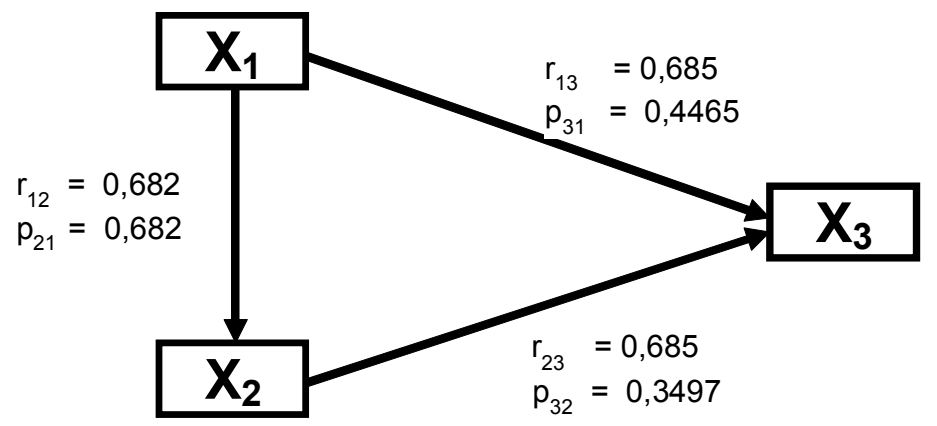

Gambar 1 Model Empiris Antarvariabel

\section{SIMPULAN DAN SARAN}

\section{Simpulan}

Berdasarkan hasil analisa dan kajian dari penelitian ini dapat disimpulkan bahwa : Pertama, efikasi diri berpengaruh langsung positif terhadap inovasi guru. Hal ini berarti bahwa dengan memiliki efikasi diri yang tinggi akan dapat meningkatkan inovasi guru. Kedua, kreativitas berpengaruh langsung positif terhadap inovasi guru. Hal ini berarti bahwa guru yang memiliki kreativitas yang tinggi akan dapat meningkatkan inovasi guru dan Ketiga; efikasi diri berpengaruh langsung positif terhadap kreativitas guru. Hal ini berarti bahwa guru yang memiliki efikasi diri yang tinggi akan dapat meningkatkan kreativitas guru.

\section{Saran}

Berdasarkan implikasi hasil penelitian yang dikemukakan di atas, dapat disampaikan saransaran praktis tentang peningkatan efikasi diri dan kreativitas dalam rangka peningkatan inovasi guru SMA negeri. Pertama, guru dituntut seyogyanya mempunyai efikasi diri yang lebih baik dalam rangka pengembangan sistem pembelajaran di sekolah melalui peningkatan kualitas belajar sehingga dapat menghasilkan inovasi guru dalam pembelajaran. Kedua, guru diharapkan lebih kreatif dalam melaksanakan tugasnya yang dapat berpengaruh terhadap peningkatan kreativitas peserta didik. Dengan demikian akan tercipta inovasi guru dalam pembelajaran di sekolah. Ketiga, melalui efikasi diri dan peningkatan keyakinan guru dalam melaksanakan berbagai model, strategi, dan fasilitas pembelajaran di kelas akan tercipta kreativitas guru yang lebih efektif dan efisien.

\section{PUSTAKA ACUAN}

Abdi, K. \& Senin, A. A. 2015. The Impact of Knowledge Management on Organizational Innovation: An Empirical Study. Journal of Asian Social Science, 11 (23), hlm. 153-168.

Acton, A. 2013. Issues in Business, Occupational, and Creative Psychology. Georgia: Scholarly Editions.

Afuah, A. 2009. Strategic Innovation: New Game Strategies for Competitive Advatage. New York Routledge.

Bandur, A. 2014. Penelitian Kualitatif: Metodologi, Desain, \& Teknik Analisis Data Dengan NVIVO 10. Jakarta: Mitra Wacana Media.

Bessant, S. \& Tidd, J. 2011. Innovation and Intrepreneurship. West Sussex: John Wiley \& Son.

Beule, F.D. \& Nauwelaerts, Y. 2013. Innovation and Creativity, Pillar of the Future Global Economy. New York: Edward Elgar Publishing Limited. 
Celik, A., Iraz, R., Cakici, A. \& Celik, N. 2014. The Effect of Employee Empowerment Applications on Organizational Creativity and Innovativeness in Enterprises: The Case of Oiz. European Scientific Journal, 10(10) hlm. 188-212.

Chin, M. K. \& Siew, N. M. 2015. The Development and Validation of a Figural Scientific Creativity Test for Preschool Pupils. Journal of Creative Education. (6), hlm. 1391-1402.

Chukwuedo, S. O., \& Omofonmwan, G. O. 2015. Practical Skills Laptop Computer Repairs for Curriculum Innovation in Technical Education Programmes in Nigeria. Journal of Education, 136(1), h/m. 74-82.

Cummings, S., Bilton, C., \& Ogilvie, D. 2015. Toward a New Understanding of Creative Dynamics: From One-Size-Fits-All Models to Multiple and Dynamic Forms of Creativity. Journal of Technology Innovation Management Review, 5(7), hlm. 14-24.

Daft, R. 2011. Leadership Fifth Edition. South Western: Cengage Learning.

Darmawan, D. 2012. Inovasi Pendidikan: Pendekatan Praktik Teknologi Multimedia dan Pembelajaran Online. Bandung: Remaja Rosdakarya.

Daryanto. 2013. Inovasi Pembelajaran Efektif. Bandung: Yrama Widya.

Degen, R. 2013. Teaching Entrepreneurship Students the Practice of Innovation: a Brain-Based Guided Experience Approach. Revista de Ciências da Administração Journal, 15(37), hlm. 92-104.

Elisondo, R., Donolo, D., \& Rinaudo, M. 2013. The Unexpected and Education: Curriculums for Creativity. Creative Education Journal, 4(12B), hlm. 11-15.

Ellitan, L. \& Anatan, L. 2009. Manajemen Inovasi: Transformasi Menuju Organisasi Kelas Dunia. Bandung: Alfabeta.

Evans, J. R. 2013. Quality Performance Excellence, Management, Organization, and Strategy. New Jersey: Cengage Learning.

Falola, T. \& Abidogun, J. 2015. Education, Creativity and Economic Empowerment in Africa. Journal of African Studies Quarterly, 15(4) hlm. 99-101.

George and Jones. 2012. Understanding and Managing Organizational Behavior, Sixth edition. New Jersey: Pearson Education, Inc.

Gibson, J., Ivancevich, J. \& R. Konopaske. 2011. Organization Behavior, Structure, Process, Fourteen Edition. Asia: Mc Graw-Hill.

Goatley, V. \& Johnston, P. 2013. Innovation, Research, and Policy: Evolutions in Classroom Teaching, Language Arts Journal, 9(2) h/m. 94-104.

Griffin \& Moorhead. 2014. Organizational: Behavior, Managing People and Organizations. South Western: Cengage Learning.

Hand, K. 2014. Building Confident Teachers: Preservice Physical Education Teachers' Efficacy Beliefs. Journal of Case Studies in Education, (6) hlm. 1-9.

Hemati, F. \& Raeesi, A. 2015. Exploring the Connection between Stability and Variability in Language Classrooms and EFL Teachers' Creativity and Burnout. Journal of Theory and Practice in Language Studies, 5(7), h/m. 1438-1445.

Hsiao, Ya-Ling, Chang \& Chen. 2011. The Influence of Teachers' Self-efficacy on Innovative Work Behavior. Interpersonal Conference on Social Science and Humanity, IPEDR Vol 5.

Iskandar, H. 2013. Wah Baru 2\% Guru yang Inovatif. http://kampus.okezone.com, diakses 18 
Maret 2013.

Jeschke \& Hees. 2013. Automation, Communication and Cybernetics in Science And Engineering. Berlin: Springer Verlag.

Joshua, H. \& Pujani, V. 2014, Customer Satisfaction in Using e-Travel: The Role of Self Efficacy, Trust, and Use, International Journal of Trade. Economics and Finance, 5(5) hlm. 459462.

Kania, B. D. 2013. In Search Of Creativity Measurement Tools, Based On The Example Of An Educational Process. Interdisciplinary Studies Journal, 2(3), hlm. 62-69.

Kim, H., Lee, E. K., \& Park, S. 2015. Critical Thinking Disposition, Self-Efficacy, and Stress of Korean Nursing Students. Indian Journal of Science and Technology, 8(18), hlm. 1-4.

Kreitner, R \& Kinichi, A. 2007. Organization Behavior. Seventh Edition. New York: McGraw Hill.

Lee, L. Y. \& Tan, E. 2012. The Influences of Antecedents o Employee Creativity and Employee Performance: A Meta Analytic Review. Interdisciplinary Journal of Contemporary Research in Business, 4(2), h/m. 984-996.

Lin, M., Chuang, T. \& Hsu, H. 2014. The Relationship among Teaching Beliefs, Student-Centred Teaching Concept and the Instructional Innovation. Journal of Service Science and Management, 7(3), h/m. 201-210.

Luthans, F. 2011. Organizational Behavior: An Evidence Based Approach. New York: McGraw-Hill.

Maktabi, S., Hanifi, F., \& Feizabadi, M. 2014. Studying on the Relation between Teachers' Creativity of Gorgan High School with their Idealistic Realistic Attitude in Year 2010-2011. Asian Journal of Research in Social Sciences and Humanities, 4(4) hlm. 74-85.

Mall-Amiri, B., \& Fekrazad, A. A. 2015. The Relationship among Iranian EFL Learners' Creativity, Emotional Intelligence, and Language Learning Strategies. Journal of Theory and Practice in Language Studies, 5(9) h/m. 1863-1873.

Martin. 2008. Creativity: Ethics and Excellence in Science. Lanham: Rowman \& Littlefield Publishing Group.

Moalosi, W. T. S., \& Forcheh, N. 2015. Self-Efficacy Levels and Gender Differentials among Teacher Trainees in Colleges of Education in Botswana. Journal of Education and Learning, 4(3), h/m. 1-13.

Mumford, M. 2012. Handbook of Organizational Creativity. Oxford : Elsevier.

Mullins, L. 2005. Management and Organizational Behavior, Seventh Edition. London: Prentice Hall.

Mulyasa, E. 2010. Menjadi Guru Profesional: Menciptakan Pembelajaran Kreatif dan Menyenangkan. Bandung: Remaja Rosdakarya.

Ng'ang'a, S. 2013. Constructivism and the Likert Scale on the Perception of Teaching/Learning Creativity at the University Level. Journal of Sociological Research, 4(1), h/m. 19-48.

Okpara, F. 2007. The Value of Creativity and Innovation in Intrepreneurship. Journal of Asia Entrepreneurship and Sustainability, III (2), hlm. 64-92.

Peter, G., \& James, S. 2015. China: Bubble-Up Innovation. Journal of Advances In Management, 8(8) $\mathrm{hlm} .1-9$.

Philips \& Gully. 2012. Organizational Behavior. Canada: South Western.

Pitsis, Simpson \& Dehlin. 2012. Handbook of Organizational and Managerial Innovation, 
Massachussets: Edward Elgar Publishing, Inc.

Pisanu, F. \& Menapace, P. 2014. Creativity \& Innovation: Four Key Issues from a Literature Review. Creative Education Journal, 5(3) hlm. 145-154.

Rachmawan, A., Lizar, A. A., \& Mangundjaya, W. L. H. 2015. The Role of Parent's Influence and Self-Efficacy on Entrepreneurial Intention. The Journal of Developing Areas, 49(3), h/m. 417-430.

Reiljan, J., \& Paltser, I. 2015. The Role of Innovation Policy in the National Innovation System: The Case of Estonia. Journal of Trames, 19(3) h/m. 249-272.

Robbins \& Judge. 2013. Organizational Behavior. New Jersey: Pearson Education Inc.

Saepulloh, A. 2014. Data Primer Hasil Interview tentang Sistem Pendidikan di Kabupaten Bekasi. Pembinaan Sekolah Menengah Dinas Pendidikan Kabupaten Bekasi. Interview 18 Maret 2014.

Sarjana, S. 2014. Upaya Meningkatkan Mutu Belajar Chasis Otomotif Berbasis Multimedia Kelas XI Teknik Kendaraan Ringan. Jurnal Pendidikan dan Kebudayaan, 20(1), hlm. 30-43.

Sarjana, S. 2015. Dynamic Capabilities in Manufacturing: The Main Role of Manufacturing Capability, Knowledge Resources and Environmental Turbulence to Improve Enterprise Performance. Journal of Entrepreneurship, Business, and Economics, 3(2), h/m. 41-64.

Sattler, M. 2011. Excellence in Innovation Management: A Meta-Analytic Review on the Predictors of Innovation Performance. Germany: Gabler Verlag.

Sa'ud, U. S. 2012. Inovasi Pendidikan. Bandung: Alfabeta.

Schermerhorn, J. R., Hunt, J., \& Osborn, R. N. 2010. Organizational Behavior. John Wiley.

Schmitt, N. W., \& Highhouse, S. 2012. Handbook of Psychology, Industrial and Organizational Psychology, Second Edition, Vol 12.

Stamm, B. 2008. Managing Innovation, Design and Creativity, Second Edition. West Sussex: John Wiley \& Sons.

Sugiyono. 2009. Statistika Untuk Penelitian. Bandung: Alfabeta.

Sun, L. 2013. Core Competences, Supply Chain Partners' Knowledge-Sharing, and Innovation: An Empirical Study of the Manufacturing Industry in Taiwan. International Journal of Business and Information. 8(2) hlm. 299-324.

Swanepoel, S., Botha, P. A., \& Rose-Innes, R. 2015. Organizational Behaviour: Exploring the Relationship Between Ethical Climate, Self-Efficacy And Hope. The Journal of Applied Business Research, 31(4) hlm. 1409-1424.

Undang-Undang Republik Indonesia Nomor 20 Tahun 2003 tentang Sistem Pendidikan Nasional.

Vadahi, F., \& Lesha, J. 2015. Enhancing Teachers Self-Efficacy: Theoretical and Research Considerations. European Scientific Journal, 11(19) hlm. 82-89.

Web, J. 2011. The Digital Innovation Playbook: Creating a Transformative Customer Experience. New Jersey: John Wiley \& Son Inc.

White \& Bruton. 2011. The Management of Technology and Innovation: A Strategic Approach. South Western: Cengage Learning.

Zakeri, S. \& Shahtalebi, B, 2014. Investigate the Relationship Between Job Autonomy And SelfEfficacy (Case Study: Technical And Vocational Education Staff Of South Khorasan Province). Journal of Business and Management Review, 4(3), hlm. 81-87. 
Jurnal Pendidikan dan Kebudayaan, Vol. 21, Nomor 3, Desember 2015 